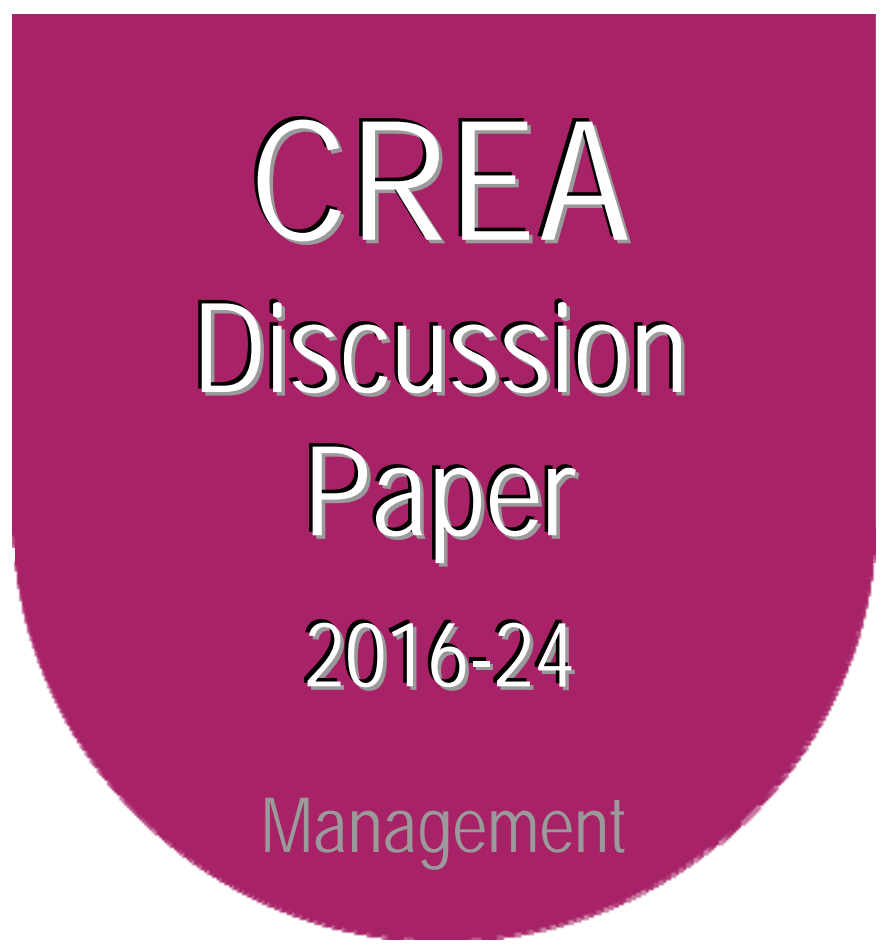

Centre for Research in Economics and Management University of Luxembourg

\title{
In Search for the Not-Invented-Here Syndrome: The Role of Knowledge Sources and Firm Success
}

available online : http://wwwfr.uni.lu/recherche/fdef/crea/publications2/discussion_papers

Katrin Hussinger, CREA, University of Luxembourg Annelies Wastyn, IDEA Consult, Brussels, Belgium

November, 2016

For editorial correspondence, please contact: crea@uni.lu

University of Luxembourg

Faculty of Law, Economics and Finance

162A, avenue de la Faïencerie

L-1511 Luxembourg

The opinions and results mentioned in this paper do not reflect the position of the Institution 


\title{
In Search for the Not-Invented-Here Syndrome: The Role of Knowledge Sources and Firm Success
}

\author{
Katrin Hussinger and Annelies Wastyn
}

This paper is published in $R \& D$ Management

\begin{abstract}
The not-invented-here $(\mathrm{NIH})$ syndrome refers to a negative attitude of employees against externally developed knowledge. We show that the sources of external knowledge and the success of the company that acquires knowledge externally are factors that impact the occurrence of an NIH syndrome. In line with social identity theory, we hypothesize that internal resistance is most likely to occur if knowledge is acquired from similar organizations. This hypothesis is supported by our empirical finding that internal resistance against external knowledge is more likely to occur when knowledge is acquired from competitors rather than from suppliers, customers or universities. Further, we show that the NIH syndrome is more likely to arise within successful companies that acquire knowledge from competitors. This is in line with our hypothesis that firm success increases the extent to which employees identify themselves with their company resulting in stronger in-group favoritism and a superior tendency to reject externally generated knowledge.
\end{abstract}

Keywords: not-invented-here syndrome; external knowledge sources; firm success; social identity theory; organizational identity

JEL: O31, O32, O33

Katrin Hussinger (corresponding author): University of Luxembourg, Center for Research in Economics and Management, 162 Avenue de la Faïencerie, 1511 Luxembourg, Luxembourg, phone: +352 466644 6404, fax: +352 466644 6341, e-mail: katrin.hussinger@uni.lu

Annelies Wastyn: IDEA Consult, Avenue des Arts 1-2/ B 16, 1210 Brussels, Belgium, phone: +32 228217 10, fax: +32 228217 15, email: Annelies.Wastyn@ideaconsult.be

Acknowledgements: We thank Rene Belderbos, Bruno Cassiman, Maarten Cuijpers, Dirk Czarnitzki, Christoph Grimpe, Hannes Günter, Paul Jensen and Bart Van Looy for helpful comments. We also thank the participants of the CISS summer school 2011 and the participants of the DRUID 2011 for helpful discussion. This paper was nominated for the best paper award at the DRUID 2011. 


\section{Introduction}

Innovation management has to pay careful attention to the fact that the institutional locus of technological advances can lie beyond the firm's boundaries (Teece, 1986; 1992). A skillful combination of externally acquired knowledge with the firm's own knowledge base can have substantial effects on firm performance and competitiveness (e.g. Kogut and Zander, 1992; Teece, 1986; 1992; Laurensen and Salter, 2006; Chesbrough, 2003; Rosenkopf and Nerkar, 2001; Cassiman and Veugelers, 2006; Huizingh, 2011; Lichtenthaler, 2011).

Successful adaption and implementation of acquired technologies relies, however, crucially on the openness of the individual employees towards externally developed technologies (Clagett, 1967; Lichtenthaler and Ernst, 2006). A welcoming attitude of employees towards new ideas cannot be taken for granted though (Clagett, 1967; Katz and Allen, 1982). This is because individuals embedded in knowledge creation processes develop routines, beliefs, artifacts, and habits in order to cope with complexities (Dosi, 1982; Nelson and Winter, 1982; Teece et al., 2001; Garud and Rappa, 1994; Szulanski, 1999; Garud and Karnoe, 2001). Routines reinforce path-dependencies and limit the rate of integration of external knowledge and the production of radical innovations though (Tripsas, 1997; Leonard-Barton, 1992). The assimilation of externally generated knowledge requires individuals to change beliefs, to look beyond the boundaries of their communities and to break with routines.

Changing beliefs and breaking with routines can be a challenge. Within their company, individuals strive for self-enhancement so that they tend to favor their company, their "ingroup”, over other companies and aim for a positive distinction from other companies, their “out-groups” (Ashfort and Mael, 1989; Bartel, 2001). The acceptance of externally generated technologies enforces a comparison of the in-group's technological expertise with that of the out-group. This can constitute a threat for the perceived expertise of a group and, hence, for the self-concept of the group and its members. Employees, working teams and communities can respond to this threat with resistance towards externally developed knowledge. A 
negative attitude towards externally developed knowledge is referred to as the not-inventedhere (NIH) syndrome (Clagett, 1967; Katz and Allen, 1982).

Although an often discussed phenomenon among practitioners, the NIH syndrome has received relatively little attention in the academic literature (see Antons and Piller, 2015, for a recent survey). The focus of previous studies is on the antecedents of the NIH-syndrome such as group tenure (Katz and Allen, 1982), the lack of or negative group experience with external knowledge (Mehrwald, 1999), dysfunctional intra-organizational communication (Mehrwald, 1999) or inappropriate incentive systems (de Pay, 1989; 1995a; b; Mehrwald, 1999).

This study contributes to our understanding of the NIH syndrome by arguing that not only project-related and team-related factors have an impact on the occurrence of an NIH syndrome. We provide a theoretical framework that suggests that the source of externally generated knowledge and the success of the knowledge sourcing company are important antecedents for the NIH syndrome as well. Building on social identity theory (Tajfel, 1974; 1978; 1982; Tajfel and Turner, 1979; 1986; Turner et al., 1987) and the concept of organizational identity (Ashfort and Mael, 1989; Dutton et al., 1994), we suggest that a rejection of external knowledge is most likely if the out-group from which the knowledge is acquired is similar to the in-group. If the out-group shares characteristics important for ingroup identification, like expertise in the same technology field or product market, individuals tend to fear their group identity threatened. In-group favoritism and a hostile behavior towards external knowledge can emerge as a defensive mechanism to restore group identity (Gabarott et al., 2009). Among different knowledge sources, competitors are the most similar out-group for companies in terms of product market and technology market expertise as compared to suppliers, customers and universities. We empirically show that internal resistance against external knowledge, as an indication of a NIH syndrome, is likely to occur when external knowledge is acquired from competitors.

Our theoretical framework further predicts a relationship between a firm's success and the occurrence of the NIH syndrome. The extent to which individuals identify themselves with 
their company increases with group success since success increases the group's distinctiveness and attractiveness (Dutton et al., 1994; Blanchard et al., 1975). A high confidence in the in-group's capabilities is often accompanied by an increased readiness to degrade outsiders' competencies and, hence, a decreased readiness to accept external knowledge (Katz and Allen, 1982). Since successful groups identify more strongly with their organization and are, hence, more likely to take defensive action against identity threats we argue and show that the most successful firms are most likely to experience the NIH syndrome when knowledge is acquired from similar sources, i.e. from competitors. The findings of our study should be of interest for managers that organize and optimize the innovation activities of companies. It is important for these decision makers to be aware of potential antecedents of a NIH syndrome in order to be able to establish means to prevent an NIH syndrome.

The remainder of the paper is organized as follows. The next section presents a review of the literature on the NIH syndrome. Section 3 develops a theoretical framework and derives hypotheses. Section 4 introduces our data set and section 5 shows the empirical results. The last section concludes.

\section{The NIH Syndrome: A Literature Review}

In the seminal study on the NIH syndrome, Clagett (1967) analyzes several cases of successful and unsuccessful implementation of process innovations reporting notable resistance against externally developed knowledge. Clagett (1967) emphasizes the importance of individuals in order to prevent an NIH syndrome. Katz and Allen (1982) and Mehrwald (1999) stress the importance of group characteristics such as project team tenure and team experience with external knowledge. ${ }^{1}$ De Pay (1989; 1995a; b) shows that miscommunication within an organization and inappropriate incentive systems can be further antecedents of the NIH syndrome. Burcharth et al. (2014) adds that nurturing special talents can lead to an NIH syndrome.

\footnotetext{
${ }^{1}$ Overall, Katz and Allen (1982) find a curvilinear effect with regards to team tenure.
} 
Lichtenthaler and Ernst (2006) and Antons and Piller (2015) provide literature reviews and conceptual frameworks for understanding the NIH syndrome. Lichtenthaler and Ernst (2006) define knowledge management consisting of three "knowledge management cycles": knowledge acquisition, knowledge accumulation and knowledge exploitation (Argote et al., 2003). At each cycle, an excessive negative attitude towards external knowledge but also an excessively positive attitude can occur. They argue that both extremes can be detrimental for the knowledge management within the organization. Antons and Piller (2015) use a different approach distinguishing between different behavioral trajectories of attitudinal functions and relate them to the NIH syndrome.

While the early studies have focused on the NIH syndrome within individual project teams some recent studies employed different perspectives on the phenomenon. Agrawal et al. (2010) examine the NIH syndrome employing a geographical focus and a firm level analysis. They find that especially large companies in the most innovative regions of the U.S. are susceptible to a NIH syndrome. Companies' tendency to build on own prior inventions disregarding externally developed ideas leads to patens of lower importance. Kathoefer and Leker (2011) shed light on the NIH syndrome in an academic environment concluding that the project experience and the attitude of professors towards science impact the likelihood of an NIH syndrome.

The NIH syndrome, as we perceive it, situates at the knowledge acquisition level of companies. We contribute to the literature by proposing the source of external knowledge and company success as further antecedents of the NIH syndrome.

\section{Theoretical Framework}

\subsection{Sources of External Knowledge and the NIH Syndrome}

Knowledge creation is a complex process involving different tasks and individuals with different backgrounds, interests and information. In order to facilitate the knowledge creation process organizations develop routines. Individuals and teams develop subroutines within the 
organizational context in order to support information processing and problem solving (Dosi, 1982; Nelson and Winter, 1982; Szulanski, 1996; Garud and Karnoe, 2001; Van Looy et al., 2001). Such routines evolve over time and are mainly tacit so that they are difficult to be imitated or changed (Teece et al., 2001). They create strong path-dependencies regarding the firm's innovation process. ${ }^{2}$ Path-dependencies support cumulativeness in innovation and facilitate routinized tasks but are not supportive of changes (Cohen and Levinthal, 1990; Leonard-Barton, 1992).

Path-dependencies are fostered by community formation, and vice versa. Within communities, common beliefs, artifacts and habits are developed alongside daily activities that create powerful path-dependencies (Van Looy et al., 2001). Such path dependencies affect the formation of expectations and the self-concept of individuals and teams (Garud and Rappa, 1994). Individuals identify themselves with their in-group and relate their self-concept and self-esteem to group membership as predicted by social identity theory (Tajfel, 1974; 1978; 1982; Tajfel and Turner, 1979; 1986; Turner et al., 1987) and the concept of organizational identity (Ashford and Mael, 1998; Dutton et al. 1994). Individuals strive for a positive social identity and engage in self-enhancement within their organization (Tajfel and Turner, 1986; Ahford and Mael, 1998) which can lead to in-group favoritism (Brewer, 1979; Ashforth and Mael, 1989; Abrams and Hogg, 1990; Tajfel and Turner, 1986). If individuals feel their organizational identity threatened they show a hostile behavior protecting their organization's self-concept.

External knowledge is a factor that can threaten the self-concept of organizational entities. The confrontation with external knowledge enforces social comparison between the in-group and the knowledge producing out-group and leads to a re-evaluation of the own organizational identity (Bartel, 2001). The acceptance and valuation of external knowledge can be perceived by insiders as a degradation of the own achievements, expertise and

\footnotetext{
${ }^{2}$ Garud and Karnoe (2001) define path-dependence as "a sequence of events constituting a self-reinforcing process that unfolds into one of several potential states. The specific state that eventually emerges depends on the particular sequence of events that unfold". 
competence of the in-group. In consequence, individuals may reject external ideas to defend their group identity (Tajfel and Turner, 1979; Brown, 2000). This attitude renders the acceptance, integration and application of external knowledge difficult or impossible: the NIH syndrome occurs. Hence, our first hypothesis reads:

Hypothesis 1: External knowledge sourcing increases the likelihood of internal resistance against new innovation projects.

As argued above, internal resistance against external knowledge, the NIH syndrome, is consistent with the concept of in-group favoritism. Two important results of social and organizational identity theory suggest that the out-group that generated the externally acquired knowledge should deserve attention when analyzing the occurrence of the NIH syndrome.

First, organizations tend to compare themselves with similar organizations (Ashforth and Mael, 1989; Bartel, 2001). Tensions and the feeling that the in-group’s identity is threatened by outsiders intensify with increasing similarity between in-group and out-group (Tajfel, 1974; Tajfel, 1982; Abrams and Hogg, 1990; Branscombe et al., 1999) because similarity between groups increases their comparability (Caddick, 1982) and the boundaries between groups threaten to obliterate (Sanchez-Mazas et al., 1994). Individuals react with increased efforts to reassure distinctiveness and to reinstall the boundaries between groups which, in turn, strengthens the in-group bias (Jetten et al., 2003).

Second, individuals and organizations are capable of making social comparisons on multiple dimensions. In this sense, organizations can appreciate each other's expertise when they are superior on complementary or distinct dimensions (Ashforth and Mael, 1989). Ingroup favoritism is strongest on dimensions regarded as important for the in-group while outgroup favoritism is likely to occur on dimensions that are less important for the in-group (Mummendey and Schreiber, 1984). In other words, groups are able to acknowledge each other's differential expertise without compromising a positive differentiation. Applying these 
results to external knowledge acquisitions suggests that the source of external knowledge matters.

\subsubsection{Heterogeneity of Knowledge Sources}

Previous innovation literature has acknowledged the heterogeneity of different sources of external knowledge and its contribution to firm performance and innovation (e.g. Belderbos et al., 2004a; b). Prior studies distinguish between knowledge acquired from vertical partners (customer and suppliers), competitors and universities.

Knowledge from (lead) customers can help defining innovations and reduce the risk associated with market introduction (Von Hippel, 1988; Brown and Eisenhardt, 1995). Innovations triggered by user needs can become a dominant design (Utterback, 1994). In addition, information from customers can support balancing performance and price. Customer knowledge can be, in particular, important for the development of novel and complex new products (Tether, 2002).

Supplier knowledge has been shown to be important for cost reductions within the firms' production process and product quality enhancements (Choi et al., 1996; Ireland et al., 2002; Belderbos et al., 2004b). Information from suppliers can spur a fast delivery and decrease production lead time (Choi et al., 1996).

Universities and public research institutions are important sources of science-based knowledge. Scientific knowledge can increase firms' understanding of recent scientific and engineering advances, facilitate the recruitment of R\&D personnel, grant access to scientific networks and reduce costs of in-house R\&D (Klevorick et al., 1995; De Backere and Veugelers, 2005). Knowledge from universities is often sourced when firms aim at creating entirely new technology markets so that science can provide a roadmap for industrial research (Tether, 2002; Fleming and Sorensen, 2004). Firms also source patented knowledge from universities that has the power to block competitors (Czarnitzki et al., 2012). In addition, the generic nature of knowledge from universities and public research institutions is less likely to 
lead to appropriation issues as compared to rather applied knowledge produced for subsequent commercialization (Cassiman and Veugelers, 2002; Czarnitzki et al., 2015).

Among the knowledge sources discussed here competitors are the most sensitive source of knowledge. Competitors operate similar products and technologies in the same market under the same economic conditions, such as industry regulations, so that rivals' knowledge is most similar to the knowledge of the firm itself and may therefore be most valuable for improving own products, processes and strategies. Too close ties to product or technology market rivals, however, bear the risk of leakage of important own technological advances, on the one hand, and of disclosing own strengths and weaknesses, on the other hand. This information can strengthen rivals. Accordingly, firms are reluctant to share knowledge with rivals since appropriation is crucial (Czarnitzki et al., 2015).

\subsubsection{Heterogeneous Knowledge Sources through a Social Identity Theory Lens}

Social identity theory indicates that social comparison is most crucial when it affects similar organizations (Tajfel and Turner, 1986; Abrams and Hogg, 1990; Branscombe et al., 1999). With regard to external knowledge sources, competitors are the most similar type of organization. Competitors can hence be considered the most interesting source of knowledge for the focal company since they have the most relevant knowledge about markets, products and technologies.

The valuation of competitors' knowledge, technologies and products by corporate insiders goes hand in hand with a comparison of the focal firm and the competitor along the same dimensions of expertise (Caddick, 1982). The appreciation of competitors' knowledge and technologies, therefor, enforces the acknowledgment of own strengths and weaknesses. Social comparison with competitors can trigger a strong need to differentiate the in-group from the out-group (Sanchez-Mazas et al., 1994). Individuals can react with increased efforts to reassure distinctiveness and to reinstall the boundaries between groups in order to protect their self-concept and the identity and integrity of their company (Jetten et al., 2003). 
Resistance against competitor knowledge or degradation of external knowledge from rivals can occur in response.

With regards to other types of knowledge sources, organizations can make social comparisons along different dimensions and value complementary or different knowledge (Tajfel and Turner, 1986). Comparisons can be made along different dimensions so that the competencies of suppliers, customers and universities can be acknowledged without threatening the organizational identity of the firm. Along these lines, we hypothesize:

Hypothesis 2: External knowledge sourcing from competitors increases the likelihood of internal resistance against new innovation projects more strongly than external knowledge sourcing from vertical partners and universities.

\subsection{Firm Success and the NIH Syndrome}

In-group favoritism can also be determined by the extent to which individuals identify with the in-group. If the in-group consists of individuals that show a strong identification with the group there is a superior tendency towards in-group favoritism and a high willingness to take defensive actions against out-groups (Branscombe et al., 1993; Doosje et al., 1995; Spears et al., 1997). Group members that identify strongly with their in-group are motivated to differentiate themselves from the out-group. In case identification with the group is low group members may be insufficiently aware of or only marginally interested in group identity so that they do not take actions to preserve group identity (Jetten et al., 2003).

The extent to which individuals identify themselves with their company increases with relative group success since success increases the group's distinctiveness and attractiveness (Dutton et al., 1994; Blanchard et al., 1975). The more successful a group is the more selfesteem and satisfaction its members can derive from social comparison to other organizations, the more individuals are tied to their organization. The willingness to take defensive actions against out-groups is higher for groups of high identifiers (Branscombe et al., 1993; Doosje et al., 1995; Spears et al., 1997) because the valuation of out-groups can evoke the feeling of 
inferiority vis-à-vis out-groups so that the self-esteem of a group members is threatened (Nadler, 1991; Nadler and Fisher, 1986). Hence, we suggest that internal resistance against external knowledge is strongest within successful firms.

Hypothesis 3a: External knowledge sourcing increases the likelihood of internal resistance against new innovation projects more strongly for top performers.

A strong identification with the group is expected to lead to a higher likelihood that external knowledge generated by similar out-groups, i.e. competitors, is rejected because knowledge from such sources constitutes the biggest threat to the group identity. Hence, we hypothesize:

Hypothesis 3b: External knowledge sourcing from competitors increases the likelihood of internal resistance against new innovation projects more strongly for top performers.

\section{Data, Definition of Variables and Descriptive Statistics}

\subsection{Data}

The empirical analysis is based on the Mannheim Innovation Panel (MIP) which is the German part of the Community Innovation Survey (CIS) of the European Commission. The CIS survey of 2003 questionnaire includes questions on internal resistance as a hampering factor for innovation activities. The survey wave 2003 constitutes a cross-sectional database for our empirical analysis. We focus on manufacturing firms only. This leaves us with a sample of 905 firms.

\subsection{Definition of Variables and Descriptive Statistics}

\subsubsection{Dependent Variable}

It is difficult to directly observe whether employees have a negative attitude towards externally developed knowledge because there are good reasons to deny a negative attitude if directly asked. In consequence, we use the survey question whether internal resistance led to project delays, cancelations or terminations in the period 2000-2002 at the firm level. If we 
find a positive relationship with externally acquired knowledge we interpret this as evidence for a NIH syndrome.

In total, 47 firms reported that at least one of their innovation projects was delayed, 20 stated that at least one innovation project was canceled and 39 reported that at least one innovation project was not started due to internal resistance. We define a binary indicator that equals one if one of the innovation obstacles occurred and zero otherwise. In total, 90 firms reported that internal resistance had a negative impact on their innovation activities. ${ }^{3}$ Descriptive statistics are presented in Table 1.

\subsubsection{Defining Top Performers}

The distinction between top performing and other firms is necessary for testing hypotheses 3a and 3b. Top performing firms are distinguished from others according to their return on sales. Since survey respondents have been found to be reluctant to report their returns on sales figures they were given seven different ranges in the survey questionnaire. The distribution of firms across the returns on sales classes is reported in Figure 1. It appears that the number of firms per return on sales class strongly decreases in class (7\%-10\%) and beyond. Hence, we use 7\% return on sales as a cut-off point to distinguish strong performers from other sample firms.

\section{Figure 1 about here}

\subsubsection{Measuring External Knowledge Inflows}

The regressors of main interest capture information about external knowledge inflows. We define a binary variable that equals one if external knowledge was acquired for a process and/or product innovation in the period 2000-2002. The majority of 617 sample firms reported external knowledge inflows. We distinguish between external knowledge acquired from competitors, suppliers or customers (vertical relationships) and scientific institutions that led to a process and/or product innovation. Most of the firms (569) acquire knowledge from

\footnotetext{
${ }^{3}$ Note that firms can report several consequences of internal resistance (delays, cancelations, not started projects) at the same time. 
vertical partners. A much smaller share of firms acquire knowledge from scientific institutions (121) and competitors (218).

\subsubsection{Control Variables}

We use a rich set of control variables. First, we use the number of employees as a measure for firm size. The conflict potential and, hence, the likelihood of internal resistance increases with the number of employees as large firms typically have a more complex organizational structure. For the empirical analysis, the logarithm of firms' labor force is used to take account of the skewness of the firm size distribution.

Moreover, we control for firms' innovation activities as measured by the firms' patent stock. ${ }^{4}$ We calculate the patent stock as follows:

$$
\text { patent stock }_{i t}=(1-.15) \text { patent stock }_{i t-1}+\text { patent applications }_{i t}
$$

We orthogonalize this variable using the firm size variable. We also control for the human capital composition within a firm's labor force by defining a variable that captures the share of low skilled workers.

Moreover, firm age is taken into account since organizational complexity is likely to increase with age. We also control for firms being part of a firm group. Lastly, we control for firms' industry affiliation by means of 9 industry dummies and for firm location in East Germany. ${ }^{5}$

\section{Table 1 about here}

\section{Empirical Results}

We test our hypotheses using a series of probability models. The dependent variable is a binary variable indicating internal resistance against innovation projects which we relate to the external knowledge acquisition. The regression results are presented in Tables 2 and Table 3.

\footnotetext{
${ }^{4}$ The survey would allow us to use firms' R\&D expenditure as a measure for their innovativeness. R\&D expenditure could, however, be influenced by our resistance variable. For instance, if an innovation project is canceled due to internal resistance the R\&D expenditure of that firm would be lower by definition.

${ }^{5}$ Bivariate correlations are presented in Table 4 in the Appendix.
} 
The first column of Table 2 presents the test for the overall presence of the NIH syndrome (hypothesis 1). The results show that the likelihood of internal resistance is not significantly affected by external knowledge inflows for the average company. Hence, hypothesis 1 does not receive support.

The second specification in Table 2 distinguishes between different sources of external knowledge by including dummy variables indicating knowledge inflow from vertical partners, competitors and scientific organizations. It appears that the NIH syndrome only occurs for knowledge inflows from competitors, confirming hypothesis 2. External knowledge from competitors increase the likelihood of internal resistance increases by $35 \%$ at the means of all other variables. ${ }^{6}$ This finding is in line with the prediction that resistance is strongest if the out-group is similar to the in-group.

With regard to the control variables the results show that internal resistance is mainly determined by firm size. The larger the firm, the more complex the organization and the greater the conflict potential. Most other variables do not impact on the likelihood of internal resistance. $^{7,8}$

\section{Table 2 about here}

Table 3 shows the regression results for hypotheses $3 \mathrm{a}$ and $3 \mathrm{~b}$. We distinguish between the top performing firms and firms with a medium or low performance. ${ }^{9}$ The results show that there is no evidence for a higher likelihood of internal resistance if firms experience external knowledge inflows from any type of source, neither among the top performing firms (column

\footnotetext{
${ }^{6}$ The percentage change is the marginal effect for a discrete change of the dummy variable from zero to one.

${ }^{7}$ LR-tests for the joint significance of the industry dummies cannot reject the null hypothesis that they are not jointly different from zero. The LR-test statistics are 4.26 for the first specification of Table 2 and 4.24 for the second specification respectively.

${ }^{8}$ The survey further allows distinguishing between knowledge flows related to product and process innovation. If we do this, we find that the results for knowledge inflows from competitors are driven by the product related innovation inflows. This is in line with our expectations because competitors are defined as rivals on the product market. This is also in line with the presumption that the type of knowledge matters and should receive further attention. Results are available from the authors upon request.

${ }^{9}$ We investigated whether there are systematic differences in terms of returns to sales between knowledge sourcing companies and others. Both firm groups have on average $2 \%-4 \%$ returns to sales. Since return to sales is measured as a categorical variable, we conducted a $\mathrm{X}^{2}$ test. Equality of the distribution for firms sourcing externally and others could not be rejected. 
2) nor among the less well performing firms (column 1). We, hence, do not find support for hypothesis 3a.

Columns 3 and 4 show the results distinguishing between different knowledge sources. It appears that the top performing firms are more likely to experience internal resistance if knowledge is acquired from competitors while there is no such effect for the less well performing firms. This supports hypothesis $3 \mathrm{~b}$. The finding is in line with the argument that individuals within successful companies identify more strongly with their in-group so that the react defensively if their group identity is threatened by the expertise of similar groups.

Regarding the control variables, we find for the subsample of medium or low performing companies that company size matters. For this subsample, the share of low skilled workers has a significant impact as well. The higher the share of low skilled workers the lower is the likelihood of internal resistance. For top performers we find that being part of a firm group impacts the likelihood of internal resistance significantly in a positive way. ${ }^{10,11}$

\section{Table 3 about here}

\section{Concluding Remarks}

The NIH syndrome is well known among practitioners, but received relatively little attention in the academic literature (Antons and Piller, 2015). This study contributes to our understanding of the antecedents of the NIH syndrome by showing that the source of external knowledge and the success of the company matter.

Drawing from social identity theory and the concept of organizational identity, we argue and show that internal resistance against external knowledge is strongest if the out-group from which the knowledge is acquired is similar to the in-group. If the out-group shares

\footnotetext{
${ }^{10}$ If the top performing firms are treated separately, industry effects matter. LR-tests reject that the eight industry dummies are jointly equal to zero at the $5 \%$ level of statistical significance (LR $=8.22^{* *}$ for model II; LR $=$ 8.35** for model IV). For the subsample of low and medium well performing firms the LR-tests on joint significance are not statistically different from zero. The LR-statistics are 7.03 for model I and 7.17 for model II. ${ }^{11}$ Since the number of firms that experience internal resistance might be considered as small (10\% of the sample), we re-estimated all models using rare event logit models (King and Zeng, 2002; Tomz et al., 2003) as robustness checks. The results are very similar to the findings presented here and are available from the authors upon request. Furthermore, our results are robust to a specification that uses interaction terms to test hypothesis 3a and 3b instead of an empirical approach that relies on a sample split. The results are available from the authors upon request.
} 
characteristics that are important for in-group identification individuals fear their group identity threatened and might take defensive actions to reinstall the boundaries between the groups. Moreover, our findings suggest that the NIH syndrome against external knowledge from competitors is more likely to occur within successful companies. The success of a firm generates satisfaction among its insiders. In-group favoritism increases as does the readiness of insiders to reject external knowledge from competitors in order to avoid comparisons along the same dimensions of expertise to protect the group's distinctiveness and the self-esteem of the group and the individual members (Nadler, 1991; Nadler and Fisher, 1986). Resistance occurs as a means to affirm a positive social identity (Turner et al., 1987).

Our results have important implications for management. We have shown that it is not only individual- and team-related factors or misaligned communication and incentive schemes that facilitate the NIH syndrome as previous literature suggests, but that the source of external knowledge and company success matter as well. Managers should, hence, take the source of external knowledge into account when deciding on their knowledge integration strategies. If the loci of knowledge creation share important characteristics that are supposed to distinguish the in-group from out-groups special means should be put into place in order to support the adaption and integration of external knowledge. Means to prevent the NIH syndrome should be worked out by the management in advance. Especially the management of successful companies should be aware of their higher risk of experiencing an NIH syndrome. Upper management can take means to influence corporate social identity by stressing distinctive dimensions of competence of the company that are not shared by companies from which knowledge is sourced.

As any, our study is not free of limitations. One limitation relates to the difficulty to observe whether employees have a negative attitude towards externally developed knowledge. Therefore we use the occurrence of internal resistance at the firm level as a proxy variable. This variable only captures the most significant cases of the NIH syndrome and does not take account of individual negative attitudes that do not have direct consequences. Another 
limitation arises from the fact that we use the company as the level of analysis. As such our study has to be seen as complementary to project or team level studies.

\section{Appendix}

Table 4 about here

\section{References}

Abrams, D. and M.A. Hogg (1990). Social Identity Theory: Constructive and Critical Advances. London: Harvester Wheatsheaf.

Agrawal, A., I. Cockburn and C. Rosell (2010). Not Invented Here? Innovation in Company Towns. Journal of Urban Economics 67, 78-89.

Argote, L., B. McEvily and R. Reagans (2003). Introduction to the Special Issue on Managing Knowledge in Organizations: Creating, Retaining and Transferring Knowledge. Management Science 49(4), v-viii.

Antons, D. and F. Piller (2015). Opening the Black Box of "Not-Invented-Here": Attitudes, Decision Biases, and Behavioral Consequences. Academy of Management Perspectives, forthcoming.

Ashforth, B.E. and F. Mael (1989). Social Identity Theory and the Organization. Academy of Management Review 14(1), 20-39.

Bartel, C.A. (2001). Social Comparisons in Boundary-spanning Work: Effects of Community Outreach on Members' Organizational Identity and Identification. Administrative Science Quarterly 46, 379-413.

Belderbos, R., M. Carree, B. Diederen, B. Lokshin and R. Veugelers (2004a). Heterogeneity in R\&D Cooperation Strategies. International Journal of Industrial Organization, 22, 8-9.

Belderbos, R., M. Carree and B. Lokshin (2004b). Cooperative R\&D and Firm Performance. Research Policy 33(10), 1477-1492.

Blanchard, F.A., L. Adelman and S.W. Cook (1975). Effect of Group Success and Failure upon Interpersonal Attraction in Cooperating Interracial Groups. Journal of Personality and Social Psychology 31, 1020-1030.

Branscombe, N.R., D.L. Wann, J.G. Noel and J. Coleman (1993). In-group and Outgroup Extremity: Importance of the Threatened Social Identity. Personality and Social Psychological Bulletin 19(4), 381-388.

Brewer, M.B. (1979). In-Group Bias in the Minimal Intergroup Situation: A Cognitive-Motivational Analysis. Psychological Bulletin 86(2), 307-324.

Brown, R. (2000). Social Identity Theory: Past Achievements, Current Problems and Future Challenges. European Journal of Social Psychology 30, 745-778. 
Brown, S.L. and K.M. Eisenhardt (1995). Product Development: Past Research, Present Findings, and Future Directions. Academy of Management Review 20(2), 343-378.

Burcharth, A. L. de A., M.P. Knudsen and H.A. Søndergaard (2014). Neither Invented nor Shared Here: The Impact and Management of Attitudes for the Adoption of Open Innovation Practices. Technovation (34), 149-161.

Caddick, D. (1982). Perceived illegitimacy and intergroup relations. In Tajfel (ed.): Social Identity and Intergroup Relations, 137-154. Cambridge, UK: Cambridge University Press.

Cassiman, B. and R. Veugelers (2002). R\&D Cooperation and Spillovers: Some Empirical Evidence from Belgium. American Economic Review 92(4), 1169-1184.

Cassiman, B. and R. Veugelers (2006). In Search of Complementarity in Innovation Strategy: Internal R\&D and External Knowledge Acquisition. Management Science 52(1), 68-82.

Chesbrough, H. (2003). Open Innovation: The New Imperative for Creating and Profiting from Technology. Boston: Harvard Business School Press, 2003.

Clagett, R.P. (1967). Receptivity to Innovation - Overcoming N.I.H. Master thesis, MIT.

Choi, T.Y. and J.L. Hartley (1996). An Exploration of Supplier Selection Practices across the Supply Chain. Journal of Operations Management 14, 333-343.

Cohen, W.M. and D.A. Levinthal (1990). Absorptive Capacity: A New Perspective on Learning and Innovation. Administrative Science Quarterly 35(1), 128-152.

Czarnitzki, D., K. Hussinger and C. Schneider (2012). The Nexus between Science and Industry: Evidence from Faculty Inventions, Journal of Technology Transfer 37(5), 755-776.

Czarnitzki, D., K. Hussinger and C. Schneider (2015), R\&D Collaboration with Uncertain Intellectual Property Rights. Review of Industrial Organization 46(2), 183-204.

De Pay, D. (1989). Kulturspezifische Determinanten der Organization von Innovationsprozessen. Zeitschrift für Betriebswirtschaft, Ergänzungsheft 1, 131167.

De Pay, D. (1995a). Informationsmanagement von Innovationen. Gabler, Wiesbaden.

De Pay, D. (1995b). Organisationsmassnahmen zur Verkürzung der Innovationszeit Europäischer Unternehmen. Zeitschrift für Betriebswirtschaft. Ergänzungsheft 1, 77-102.

Doosje, B., N. Ellemers, and R. Spears (1995). Perceived Intragroup Variability as a Function of Group Status and Identification. Journal of Experimental Social Psychology 31, 410-436.

Dosi, G. (1982). Technological Paradigms and Technological Trajectories: A Suggested Interpretation of the Determinants and Directions of Technical Change. Research Policy 11(3), 147-162.

Dutton, J.E., J.M. Dukerich and C.V. Harquail (1994). Organizational Images and Member Identification. Administrative Science Quarterly 39(2), 239-263. 
Fleming, L. and O. Sorensen (2004). Science as a Map in Technology Search. Strategic Management Journal 25(89), 909-928.

Gabarott, F., J.M. Falomir-Pichastor and G. Mugny (2009). Being Similar versus Being Equal: Intergroup Similarity Moderates the Influence of In-Group Norms on Discrimination and Prejudice. British Psychology Journal 48, 253-273.

Garud, R. and P. Karnoe (2001). Path Creation as a Process of Mindful Deviation, in: Garu, R. and P. Karnoe (eds.), Path Dependence and creation, New Jersey: Lawrence Erlbaum Associates, Inc.

Garud, R. and M.A. Rappa (1994). A Socio-cognitive Model of Technology Evolution: The Case of Cochlear Implants. Organization Science 5(3), 344-345.

Huizingh, E.K.R.E. (2011). Open Innovation: State of the Art and Future Perspectives. Technovation 31, 2-9.

Ireland, R.D., M.A. Hitt and D. Vaidyanath (2002). Alliance Management as a Source of Competitive Advantage. Journal of Management 28(3), 413-446.

Jetten, J. and R. Spears (2003). The Divisive Potential of Differences and Similarities: The Role of Intergroup Distinctiveness in Intergroup Differentiation. European Review of Social Psychology 14, 203-241.

Kathoefer, D.G. and J. Leker (2011). Knowledge Transfer in Academia: An Exploratory Study on the Not-Invented-Here Syndrome. Journal of Technology Transfer 37, 658-675.

Katz, R. and T.J. Allen (1982). Investigating the Not-Invented-Here (NIH) Syndrome: A Look at the Performance, Tenure and Communication Patterns of 50 R\&D Project Groups. R\&D Management 12, 7-19.

Klevorick, A.K., R.C. Levin, R.R. Nelson and S.G. Winter (1995). On the Sources and Significance of Inter-industry Differences in Technological Opportunities. Research Policy 24(2), 185-205.

Kogut, B. and U. Zander (1992). Knowledge of the Firm, Combinative Capabilities, and the Replication of Technology. Organization Science 3(3), 383-397.

Leonard-Barton, D. (1992). Core Capabilities and Core Rigidities: A Paradox in Managing New Product Development. Strategic Management Journal 13, 111125.

Lichtenthaler, U. (2011). Open Innovation. Academy of Management Perspectives 1(25), 75-93.

Lichtenthaler, U. and H. Ernst (2006). Attitudes to Externally Organizing Knowledge Management Tasks: A Review, Reconsideration and Extension of the NIH Syndrome. R\&D Management 36(4), 367-386.

Mehrwald, H. (1999). Das 'Not Invented Here'-syndrom in Forschung und Entwicklung. Deutscher Universitaetsverlag, Wiesbaden.

Mummendey, A. and H.J. Schreiber (1984). "Different” just Means "Better”: Some Obvious and Some Hidden Pathways to In-group Favouritism. British Journal of Social Psychology 23, 363-368. 
Nadler, A. (1991). Help-Seeking Behavior, Psychological Costs and Instrumental Benefits. In: M.S. Clark (Ed.): Review of Personality and Social Psychology Vol. 12. Sage, New York.

Nadler, A. and D. Fisher (1986). The Role of Threat to Self-esteem and Perceived Control in Recipient Reaction to Help: Theory Development and Empirical Validation. In L. Berkowitz (Ed.), Advances in Experimental Social Psychology 19, New York Academic Press, New York, 81-121.

Nelson, R.R. and S.G. Winter (1982). An Evolutionary Theory of Economic Change. Belknap Press, Cambridge, MA.

Rosenkopf, L. and A. Nerkar (2001). Beyond local search: boundary-spanning, exploration, and impact in the optical disk industry. Strategic Management Journal 22(4), 287-306.

Sanchez-Mazas, M., P. Roux and G. Mugny (1994). When the Outgroup becomes InGroup and when the In-Group becomes Outgroup: Xenophobia and Social Categorization in a Resource Allocation Task. European Journal of Social Psychology 24, 417-423.

Spears, R., Doosje, B. and Ellemers, N. (1997). Self-stereotyping in the Face of Threats to Group Status and Distinctiveness: The Role of Group Identification. Personality and Social Psychology Bulletin 23, 583-553.

Szulanski, G. (1996). Exploring Internal Stickiness: Impediments to the Transfer of Best Practices within the Firm. Strategic Management Journal 17(1), 27-43.

Szulanski, G. (1999). Appropriability and the Challenge of Scope: Banc One Routinizes Replication. In G. Dosi, R.R. Nelson and S.G. Winter (eds.): Nature and Dynamics of Organizational Capabilities. Oxford University Press, New York, 69-98.

Tajfel, H. (1974). Social Identity and Intergroup Behaviour. Social Science Information 13(2), 65-93.

Tajfel, H. (Ed.). (1978). Differentiation between Social Groups: Studies in the Social Psychology of Intergroup Relations. Academic Press, London.

Tajfel, H. and J.C. Turner (1979). An Integrative Theory of Social Conflict. In W. Austin and S. Worchel (Eds), The Social Psychology of Intergroup Relations. 3347. Brooks/Cole, California.

Tajfel, H. and J.C. Turner (1986). The social identity theory of inter-group behavior. In S. Worchel \& L. W. Austin (Eds.), Psychology of Intergroup Relations. Nelson-Hall, Chicago

Tajfel, H. (1982). Social Identity and Intergroup Relations. Cambridge University Press, Cambridge.

Teece, D.J. (1986). Profiting from Technological Innovation: Implications for Integration, Collaboration, Licensing and Public Policy. Research Polic, 15(6), 285-305.

Teece, D.J. (1992). Competition, Cooperation, and Innovation: Organizational Arrangements for Regimes of Rapid Technological Progress. Journal of Economic Behavior and Organizatio, 18, 1-25. 
Teece, D.J., G. Pisano and A. Shuen (2001). Dynamic Capabilities and Strategic Management. In Dosi, G., R.R. Nelson and S. Winter (eds.), The Nature and Dynamics of Organizational Capabilities, 334-363, Oxford University Press.

Tether, B.S. (2002). Who Co-operates for Innovation, and Why: An Empirical Analysis. Research Policy 31, 947-967.

Tomz, M., G. King and L. Zeng (2003). ReLogit: Rare Ecents Logistic Regression. Journal of Statistical Software 8(2), 1-27.

Tripsas, M. (1997). Unraveling the Process of Creative Destruction: Complementary Assets and Incumbent Survival in the Typesetter Industry. Strategic Management Journal 18, 119-142

Turner, J.C., M.A. Hogg, P.J. Oakes, S.D. Reicher and M.S. Wetherell (1987). Rediscovering the Social Group: A Self-Categorization Theory. Blackwell, Oxford.

Utterback, J.M. (1994). Mastering the Dynamics of Innovation. Boston: Harvard University Press.

Van Looy, B., K. Debackere and R. Bouwen (2001). Innovation as a CommunitySpanning Process: Looking for Interaction Strategies to Handle Path Dependency, in: Garu, R. and P. Karnoe (eds.), Path Dependence and creation. Lawrence Erlbaum Associates Inc., New Jersey.

Von Hippel, E. (1988). The Sources of Innovation. Oxford University Press, New York 
TABLES \& FIGURE

Table 1: Descriptive statistics

\begin{tabular}{|c|c|c|c|c|c|}
\hline & Full sample & $\begin{array}{r}\text { Less well } \\
\text { performing } \\
\text { firms } \\
\end{array}$ & $\begin{array}{r}\text { Top } \\
\text { performers }\end{array}$ & & \\
\hline \multirow[t]{2}{*}{$\#$} & 905 & 675 & 230 & & \\
\hline & $\begin{array}{r}\text { Mean } \\
\text { (st. dev.) }\end{array}$ & $\begin{array}{r}\text { mean } \\
\text { (st. dev.) }\end{array}$ & $\begin{array}{r}\text { mean } \\
\text { (st. dev.) }\end{array}$ & $\begin{array}{l}\text { mean } \\
\text { diff. }^{\mathrm{A}}\end{array}$ & \\
\hline \multirow[t]{2}{*}{ internal resistance } & 0.10 & 0.11 & 0.08 & 0.03 & \\
\hline & $(0.30)$ & $(0.31)$ & $(0.27)$ & & \\
\hline \multirow[t]{2}{*}{ external knowledge inflows } & 0.68 & 0.67 & 0.71 & -0.04 & \\
\hline & $(0.47)$ & $(0.47)$ & $(0.45)$ & & \\
\hline \multirow[t]{2}{*}{... from vertical partners } & 0.63 & 0.63 & 0.62 & 0.01 & \\
\hline & $(0.48)$ & $(0.48)$ & $(0.49)$ & & \\
\hline \multirow[t]{2}{*}{... from competitors } & 0.24 & 0.22 & 0.31 & -0.09 & $* * *$ \\
\hline & $(0.43)$ & $(0.41)$ & $(0.46)$ & & \\
\hline ... from scientific & 0.13 & 0.12 & 0.17 & -0.05 & $* *$ \\
\hline Institutions & $(0.34)$ & $(0.33)$ & $(0.38)$ & & \\
\hline \multirow[t]{2}{*}{ number of employees } & 427.94 & 454.05 & 351.33 & 102.72 & \\
\hline & (1366.96) & $(1484.48)$ & $(939.46)$ & & \\
\hline \multirow[t]{2}{*}{ log(employees) } & 4.57 & 4.60 & 4.51 & 0.09 & \\
\hline & (1.65) & (1.66) & (1.63) & & \\
\hline share of low skilled & 81.23 & 82.16 & 78.52 & 2.64 & $* *$ \\
\hline Workers & (19.97) & (19.83) & (20.17) & & \\
\hline \multirow[t]{2}{*}{ patent stock } & 8.83 & 5.61 & 18.28 & & \\
\hline & $(132.32)$ & $(56.24)$ & $(244.32)$ & & \\
\hline \multirow[t]{2}{*}{ patent stock/employees } & 0.02 & 0.02 & 0.02 & -0.00 & \\
\hline & $(0.08)$ & $(0.07)$ & $(0.09)$ & & \\
\hline \multirow[t]{2}{*}{ East Germany } & 0.33 & 0.33 & 0.33 & 0.00 & $* *$ \\
\hline & $(0.47)$ & $(0.47)$ & $(0.47)$ & & \\
\hline \multirow[t]{2}{*}{ part of a firm group } & 0.45 & 0.43 & 0.50 & -0.07 & $* * *$ \\
\hline & $(0.50)$ & $(0.50)$ & $(0.50)$ & & \\
\hline ... with a foreign head & 0.12 & 0.10 & 0.19 & -0.09 & \\
\hline Quarter & $(0.33)$ & $(0.30)$ & $(0.39)$ & & \\
\hline \multirow[t]{2}{*}{ Age } & 31.55 & 32.30 & 29.32 & 2.98 & \\
\hline & (35.73) & (36.73) & (32.59) & & \\
\hline \multirow[t]{2}{*}{ log(age) } & 3.00 & 3.01 & 2.98 & 0.03 & \\
\hline & $(0.98)$ & $(1.01)$ & $(0.92)$ & & \\
\hline
\end{tabular}

${ }^{\mathrm{A}}$ This column shows the differences in the means of top performing and less well performing firms for the variables of interest. Significance levels of t-test for a significant difference in the means are presented in the last column.

$*, * *, * * *$ indicate $10 \%, 5 \%$ and $1 \%$ significance levels. 
Table 2: Probit models for the likelihood of internal resistance

\begin{tabular}{|c|c|c|}
\hline \multirow{3}{*}{ Estimation approach } & $\mathrm{I}$ & II \\
\hline & probit & probit \\
\hline & $\begin{array}{r}\text { coeff. } \\
\text { (s.e.) }\end{array}$ & $\begin{array}{r}\text { coeff. } \\
\text { (s.e.) }\end{array}$ \\
\hline external knowledge inflows & $\begin{array}{l}0.21 \\
(0.15)\end{array}$ & \\
\hline ... from vertical partners & & $\begin{array}{l}0.10 \\
(0.14)\end{array}$ \\
\hline ... from competitors & & $\begin{array}{l}0.27^{* *} \\
(0.13)\end{array}$ \\
\hline ... from universities & & $\begin{array}{l}0.20 \\
(0.15)\end{array}$ \\
\hline $\log$ (employees) & $\begin{array}{l}0.13^{* * *} \\
(0.04)\end{array}$ & $\begin{array}{l}0.12^{* * *} \\
(0.04)\end{array}$ \\
\hline share of low skilled workers & $\begin{array}{l}-0.01 \\
(0.00)\end{array}$ & $\begin{array}{l}-0.01 \\
(0.00)\end{array}$ \\
\hline patent stock/ employees & $\begin{array}{l}0.34 \\
(0.71)\end{array}$ & $\begin{array}{l}0.35 \\
(0.72)\end{array}$ \\
\hline East Germany & $\begin{array}{l}-0.26 * \\
(0.15)\end{array}$ & $\begin{array}{l}-0.28^{*} \\
(0.15)\end{array}$ \\
\hline part of a firm group & $\begin{array}{l}0.09 \\
(0.15)\end{array}$ & $\begin{array}{l}0.07 \\
(0.15)\end{array}$ \\
\hline ... with a foreign head quarter & $\begin{array}{l}0.01 \\
(0.18)\end{array}$ & $\begin{array}{l}0.03 \\
(0.18)\end{array}$ \\
\hline log(age) & $\begin{array}{l}-0.02 \\
(0.07)\end{array}$ & $\begin{array}{l}-0.02 \\
(0.07)\end{array}$ \\
\hline constant & $\begin{array}{l}-1.44 * * * \\
(0.43)\end{array}$ & $\begin{array}{l}-1.41^{* * *} \\
(0.43)\end{array}$ \\
\hline $\mathrm{N}$ & 905 & 905 \\
\hline Loglikelihood & -276.92 & -274.74 \\
\hline Hosmer-Lemeshow $\mathrm{X}^{2}$ & 9.29 & 8.14 \\
\hline McKelvey and Zavoina $\mathrm{R}^{2}$ & 0.10 & 0.11 \\
\hline
\end{tabular}

8 industry dummies are included in all specifications.

$*, * *, * * *$ indicate $10 \%, 5 \%$ and $1 \%$ significance levels. 
Table 3: Probit models for the likelihood of internal resistance: high performers versus median and low performers

\begin{tabular}{|c|c|c|c|c|}
\hline & I & II & III & IV \\
\hline \multirow[t]{3}{*}{ sample } & $\begin{array}{l}\text { low and } \\
\text { medium } \\
\text { performers }\end{array}$ & $\begin{array}{l}\text { high } \\
\text { performers }\end{array}$ & $\begin{array}{l}\text { low and } \\
\text { medium } \\
\text { performers }\end{array}$ & $\begin{array}{l}\text { high } \\
\text { performers }\end{array}$ \\
\hline & $\begin{array}{l}\text { return } \\
\text { on sales } \\
<=7 \%\end{array}$ & $\begin{array}{l}\text { return } \\
\text { on sales } \\
>7 \%\end{array}$ & $\begin{array}{l}\text { return } \\
\text { on sales } \\
<=7 \%\end{array}$ & $\begin{array}{l}\text { return on } \\
\text { sales } \\
>7 \%\end{array}$ \\
\hline & $\begin{array}{l}\text { coeff. } \\
\text { (s.e.) }\end{array}$ & $\begin{aligned} \text { coeff. } \\
\text { (s.e.) }\end{aligned}$ & $\begin{aligned} \text { coeff. } \\
\text { (s.e.) }\end{aligned}$ & $\begin{array}{r}\text { coeff. } \\
\text { (s.e.) }\end{array}$ \\
\hline external knowledge & 0.22 & 0.27 & & \\
\hline inflows & $(0.17)$ & $(0.37)$ & & \\
\hline $\begin{array}{l}\ldots \text { from vertical } \\
\text { partners }\end{array}$ & & & $\begin{array}{l}0.24 \\
(0.17)\end{array}$ & $\begin{array}{l}-0.67 * \\
(0.39)\end{array}$ \\
\hline ... from competitors & & & $\begin{array}{l}0.19 \\
(0.15)\end{array}$ & $\begin{array}{l}0.79 * * \\
(0.35)\end{array}$ \\
\hline ... from universities & & & $\begin{array}{l}-0.06 \\
(0.18)\end{array}$ & $\begin{array}{l}0.52 \\
(0.36)\end{array}$ \\
\hline log(employees) & $\begin{array}{l}0.16^{* * *} \\
(0.05)\end{array}$ & $\begin{array}{l}-0.03 \\
(0.12)\end{array}$ & $\begin{array}{l}0.15^{* * *} \\
(0.05)\end{array}$ & $\begin{array}{l}-0.09 \\
(0.12)\end{array}$ \\
\hline share of low skilled & $-0.01 * *$ & 0.00 & $-0.01 * *$ & 0.00 \\
\hline Workers & $(0.00)$ & $(0.01)$ & $(0.00)$ & $(0.01)$ \\
\hline patent stock/ & 0.49 & 0.29 & 0.44 & 0.44 \\
\hline Employees & $(0.87)$ & $(1.67)$ & $(0.89)$ & $(1.96)$ \\
\hline East Germany & $\begin{array}{l}-0.26 \\
(0.16)\end{array}$ & $\begin{array}{l}-0.45 \\
(0.40)\end{array}$ & $\begin{array}{l}-0.28 * \\
(0.17)\end{array}$ & $\begin{array}{l}-0.50 \\
(0.42)\end{array}$ \\
\hline part of a firm group & $\begin{array}{l}-0.14 \\
(0.17)\end{array}$ & $\begin{array}{l}1.62 * * * \\
(0.53)\end{array}$ & $\begin{array}{l}-0.14 \\
(0.17)\end{array}$ & $\begin{array}{l}1.75^{* * *} \\
(0.58)\end{array}$ \\
\hline $\begin{array}{l}\ldots \text { with a foreign } \\
\text { head quarter }\end{array}$ & $\begin{array}{l}0.13 \\
(0.23)\end{array}$ & $\begin{array}{l}-0.35 \\
(0.33)\end{array}$ & $\begin{array}{l}0.15 \\
(0.23)\end{array}$ & $\begin{array}{l}-0.37 \\
(0.37)\end{array}$ \\
\hline $\log ($ age $)$ & $\begin{array}{l}-0.04 \\
(0.07)\end{array}$ & $\begin{array}{l}0.03 \\
(0.18)\end{array}$ & $\begin{array}{l}-0.04 \\
(0.08)\end{array}$ & $\begin{array}{l}0.06 \\
(0.19)\end{array}$ \\
\hline constant & $\begin{array}{l}-1.22 * * * \\
(0.47)\end{array}$ & $\begin{array}{l}-3.63 * * * \\
(1.17)\end{array}$ & $\begin{array}{l}-1.22 * * * \\
(0.47)\end{array}$ & $\begin{array}{l}-3.58 * * * \\
(1.17)\end{array}$ \\
\hline $\mathrm{N}$ & 675 & 230 & 675 & 230 \\
\hline Loglikelihood & -215.33 & -48.06 & -213.90 & -44.17 \\
\hline $\begin{array}{l}\text { Hosmer-Lemeshow } \mathrm{X}^{2} \\
\text { McKelvey and }\end{array}$ & 5.34 & 3.45 & 4.70 & 4.01 \\
\hline Zavoina $\mathrm{R}^{2} \mathrm{~s}$ & 0.11 & 0.49 & 0.12 & 0.61 \\
\hline
\end{tabular}

8 industry dummies are included in all specifications.

$*, * *, * * *$ indicate $10 \%, 5 \%$ and $1 \%$ significance levels. 
Table 4: Bivariate correlations

\begin{tabular}{|c|c|c|c|c|c|c|c|c|c|c|c|c|}
\hline & variables & 1 & 2 & 3 & 4 & 5 & 6 & 7 & 8 & 9 & 10 & 11 \\
\hline 1 & internal resistance & & & & & & & & & & & \\
\hline 2 & external knowledge inflows & 0.07 & & & & & & & & & & \\
\hline 3 & ... from vertical partners & 0.06 & 0.87 & & & & & & & & & \\
\hline 4 & $\ldots$ from competitors & 0.13 & 0.38 & 0.22 & & & & & & & & \\
\hline 5 & ... from scientific institutions & 0.10 & 0.27 & 0.19 & 0.13 & & & & & & & \\
\hline 6 & $\log ($ employment $)$ & 0.15 & 0.10 & 0.07 & 0.18 & 0.09 & & & & & & \\
\hline 7 & share of low skilled workers & -0.02 & -0.11 & -0.12 & -0.06 & -0.21 & 0.19 & & & & & \\
\hline 8 & patent stock/employees & 0.04 & 0.06 & 0.06 & 0.00 & 0.08 & 0.02 & -0.09 & & & & \\
\hline 9 & East Germany & -0.08 & 0.05 & 0.05 & 0.04 & 0.03 & -0.21 & -0.18 & -0.07 & & & \\
\hline 10 & part of a firm group & 0.10 & 0.05 & 0.04 & 0.15 & 0.07 & 0.49 & 0.02 & 0.08 & -0.13 & & \\
\hline 11 & ... with a foreign head quarter & 0.04 & 0.00 & -0.02 & 0.01 & 0.03 & 0.21 & -0.01 & 0.02 & -0.07 & 0.42 & \\
\hline 12 & $\log ($ age $)$ & 0.04 & 0.01 & -0.02 & 0.02 & -0.05 & 0.32 & 0.25 & 0.04 & -0.37 & 0.06 & -0.01 \\
\hline
\end{tabular}


Figure 1: Return on sales distribution

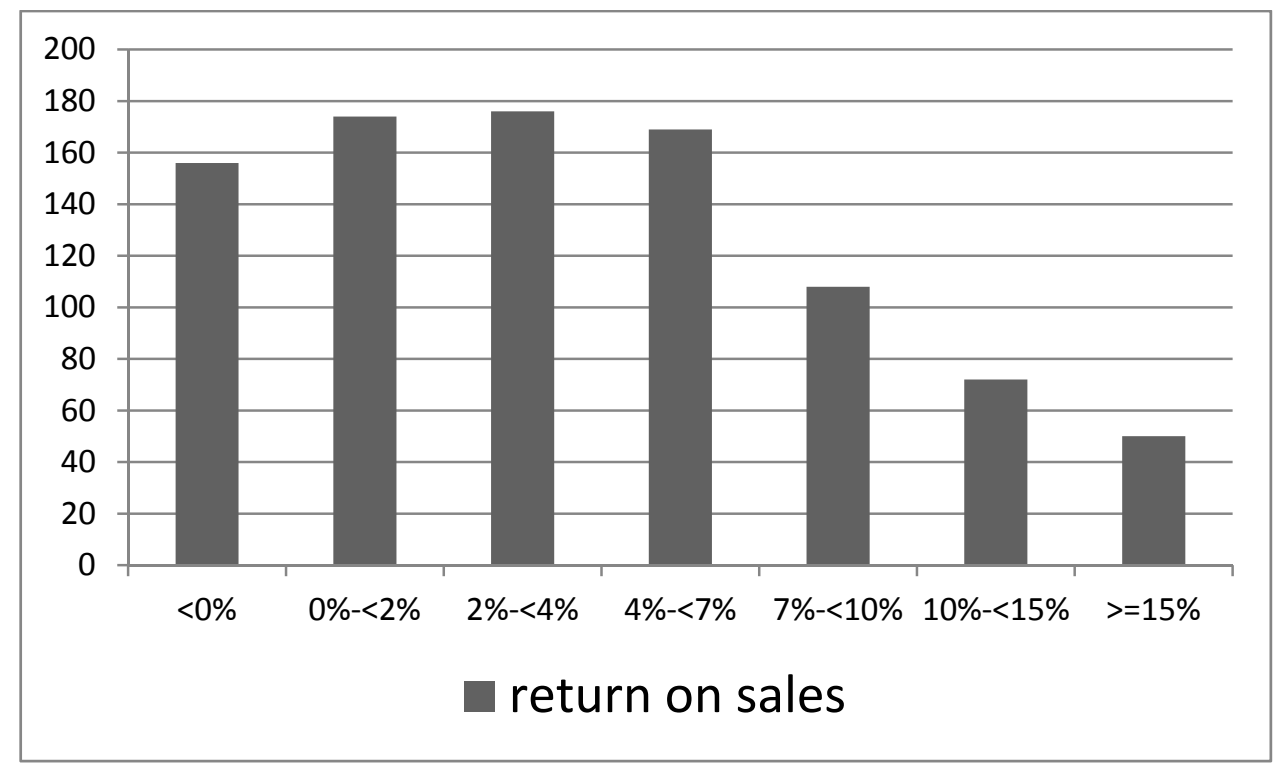

